\title{
Censorship and the American College Library
}

\section{Ronald N. Bukoff}

Censorship at American college libraries has rarely been examined at any level of study. This survey is the first to investigate systematically cases of censorship involving a representative sampling of college and university libraries at two- and four-year state and private schools. The libraries serve small colleges with student populations ranging from 501 to 5,000 students. Over one-third of all respondents replying to a questionnaire reported some type of challenges to intellectual freedom. Various categories of censorship, identification of problematic materials, and types of complainants are examined.

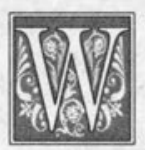

hat is censorship? Simply stated, censorship is the suppression of ideas, but as one examines the topic, the definition of this term becomes fluid and difficult to establish. In the library, acts of censorship can run the gamut from the formal request to have an item removed to anonymous acts of violence against the collection. Instances of censorship in school and public libraries are well publicized in the media and the literature, although similar cases in academic libraries rarely have come to light. Librarians and library administrators should not be lulled into a false sense of security; censorship is alive and flourishing in American college and university libraries. As libraries expand their missions to adopt new philosophies of service and provide access to information in a variety of formats, censors accompany each innovation and change.
A search of the literature reveals only two large-scale but specialized studies of censorship in college libraries: the examination of censorship in Canadian prairie province academic libraries in the early 1980s by Alvin M. Schrader, Margaret Herring, and Catriona De Scossa published in 1989; and Craighton Hippenhammer's 1993 survey of Christian college libraries in the United States and Canada. ${ }^{1}$ These authors are concerned with the problem of intellectual freedom and censorship at the college/university level. Comparison between their findings and the results of the present study will demonstrate a steady and constant rate of censorship in college libraries of the United States.

I have taken as inspiration the statement by Schrader, Herring, and De Scossa:

"To the best of our knowledge, no other comprehensive study has

Ronald N. Bukoff is the Music/Humanities Librarian at Mansfield University, Mansfield, PA 16933. The author would like to thank Judith Serebnick for her encouragement and support. Others important to the genesis of this paper are Margaret Herring; Frank Quinn, and Sylvia Turchyn; and the sixty-eight librarians who took time out of their busy schedules to respond to the questionnaire. 
been undertaken of the censorship phenomenon in the libraries of postsecondary educational institutions in either Canada or the United States ... . It is hoped that similar studies will be undertaken in the near future in many other geographic areas, nationally and internationally, so that our understanding of the issues is broadened, and so that senior administrative policymakers-and librarians-will be forewarned."2

The "near future" is at hand; this report is the first to examine censorship in the American college library on a national basis. Academic librarians can no longer promulgate the erroneous pelief that censorship cannot happen in their libraries. It can occur, it does occur, and it might happen sooner than imagined, for the most unexpected of reasons.

\section{Methodology}

The survey examined cases of censorship in college and university libraries in the United States from 1988 to 1994 . The author chose this time frame for various reasons: to allow the possibility of examining trends in the increase or decrease of censorship since earlier studies; to decrease the likelihood for respondents not

As libraries expand their missions to adopt new philosophies of service and provide access to information in a variety of formats, censors accompany each innovation and change.

remembering incidents prior to 1988 or not working at their current library before 1988; and to match the span of years studied by the Canadian survey, permitting a greater methodological relationship between the two studies. A questionnaire was sent to college and university libraries chosen in a random sampling of postsecondary institutions listed in
Peterson's Register of Higher Education, $1994 .^{3}$ Sampling was limited to schools with a student population between 501 and 5,000 and to institutions that primarily supported a liberal arts undergraduate curriculum. These are the "typical" small colleges. According to Peterson's Register, 55 percent of the colleges and universities in the United States fall into the range of 501 to 5,000 students. ${ }^{4}$ The author decided that since colleges and universities in this category-all of which will be referred henceforth as collegeswould most likely have a single, central library, the reporting of cases of censorship would be more methodical than in other libraries. Further instances of censorship would be known to the library administrators contacted. Of course, exceptions to this characterization exist, but it proved to be accurate for the majority of libraries contacted in the survey. In large academic library systems with multiple branch libraries on a single campus, knowledge of cases of censorship becomes more happenstance; events at a branch library may be handled locally and not reported to the central administrative office. The decision to concentrate on the typical liberal arts college setting, which primarily serves undergraduates, eliminated technical and professional schools from consideration.

Two- and four-year schools, both private and state, were considered valid settings. A random sampling of 110 colleges in 42 states was created and questionnaires were mailed to the selected schools in early February 1994. Within one month, respondents returned 68 questionnaires from 35 states - an acceptable response rate of 62 percent. The geographical spread between sampling and response was similar and all areas of the country were represented in an equitable manner. The questionnaires were sent to the directors of each library, on the assumption that the library heads would be aware of all cases of censorship in their libraries, or would refer the question- 
naires to the most knowledgeable staff members. This assumption appears to have been true. Out of the 68 respondents, $53(78 \%)$ were the respective heads of their libraries.

\section{Survey}

The percentage of responding libraries, according to size (number of students) and type (state or private, two- or fouryear), corresponds closely to the original sampling. Deviation between the sampling and the returns was small and indicates that the response accurately represents the original mailing. Of the $68 \mathrm{re}-$ sponding librarians, 25 libraries (37\%) recorded 38 instances of censorship, oftentimes multiple cases within a single library; eleven libraries (16\%) fell into the latter category. The total of 37 percent of censorship cases in American college libraries corresponds to the 30 percent of cases of censorship in Canadian academic libraries, 1980-1985, reported by Schrader, Herring, and De Scossa. ${ }^{5}$ However, the Canadian authors examined a wider sampling of postsecondary institutions, and schools with student bodies numbering less than 5,000 accounted for only a portion, albeit a significant portion, of the total. Schrader, Herring, and De Scossa report that 75 percent of the censorship incidents occurred in libraries connected with colleges having fewer than 5,000 students, but further examination of their figures also reveals that the eleven libraries serving fewer than 5,000 students account for 24 percent of the total number of respondents (47 libraries). ${ }^{6}$ Nevertheless, the Canadian study reveals a higher rate of censorship incidents in libraries connected with smaller colleges.

Of the responding libraries, 25 reported cases of censorship, while $43(63 \%)$ had not experienced any problems of this type. Multiple cases of censorship in a single institution are not reported separately; each library was counted once, whether or not multiple incidents occurred. In this study, the number of twoyear private institutions is quite small. Since the two out of three responding libraries in this category reported no cases of censorship, this separate category will not appear on subsequent tables. Rather, two-year state and private institutions will be combined into a single category. (See table 1.)

Although the reported incidents of censorship are spread evenly over the range of schools, by type and size, several observations can be made. Cases of censorship happen less often at schools with student bodies in the 501 to 1,250 range (six colleges, 24 percent out of the number of institutions reporting censor-

\begin{tabular}{|lcccccc|}
\hline \multicolumn{7}{c|}{ TABLE 1 } \\
\multicolumn{1}{c}{} & \multicolumn{7}{c|}{ REPORTED CASES OF CENSORSHIP (N=25) } \\
Student & 4 year & 4 year & 2 year & 2 year & & \\
population: & state & private & state & private & Total & Percent \\
\cline { 2 - 8 } $501-1,250$ & 0 & 4 & 2 & 0 & 6 & 24 \\
$1,250-2,500$ & 2 & 6 & 3 & 0 & 11 & 44 \\
$2,501-5,000$ & 1 & 3 & 4 & 0 & 8 & 32 \\
Total & 3 & 13 & 9 & 0 & 25 & $100 \%$ \\
Percent & 12 & 52 & 36 & 0 & $100 \%$ & \\
\hline
\end{tabular}


ship), and most frequently at schools with 1,251 to 2,500 students (eleven colleges, $44 \%)$. The range of difference is even higher when types of schools are compared. Four-year state colleges reported only three cases of censorship (12\%), while four-year private colleges have the highest rate of censorship with twelve occurrences (48\%). Two-year institutions fall between these two extremes with nine incidents (36\%). This last number represents both state and private two-year colleges. When type and size are combined, four-year private colleges with 1,251 to 2,500 students have the highest percentage of cases of censorship (six incidents, $24 \%$ ) out of the total number of responding libraries.

When all four-year private colleges are examined, the 13 cases in this category account for 52 percent of the total number of challenges to the library. This number is impressive, but it seems expedient to separate four-year private colleges into two categories: religious and nondenominational. With this in mind, the figure of 52 percent needs to be reexamined. Twenty-three religious-affiliated colleges replied to the survey, while seven nondenominational private colleges responded. Of the religious colleges, ten recorded instances of censorship, 40 percent of the total, while nondenominational colleges accounted for 12 percent. These are very different figures, but single numbers can be misleading. A division of the percentage of libraries reporting cen- sorship, out of the number of responding libraries in each category, is provided in table 2.

When examined within separate categories, the numbers reveal a different perspective. Four-year state colleges report the lowest percentage of censorship cases, although the figure of 23 percent is still substantial. Nearly one-quarter of schools in this category have experienced some form of censorship within the last five years. Two-year colleges, both private and state, recorded a 36 percent rate of censorship, while the four-year private schools, both religious and nondenominational, averaged 43 percent each. Examined by individual categories, the religious and nondenominational colleges are remarkably similar, with very high rates of experienced censorship.

The four-year religious colleges responding to the survey represented many types of Western Christian theology, conservative to liberal. A comparison can be made with Hippenhammer's survey of evangelical Christian college libraries. Hippenhammer reports that 48 percent of the libraries in his survey encountered some type of censorship during the last two years. ${ }^{7}$ Although his study focused on conservative evangelical colleges, and the present study examines the entire spectrum of religious-affiliated schools, the present finding of 43 percent of cases of censorship within all types of religiousaffiliated four-year colleges compares closely to Hippenhammer's report of 48

\section{TABLE 2}

\section{Percentage of Libraries Reporting Censorship}

\begin{tabular}{lcc}
\hline \hline & Cases of censorship & $\begin{array}{c}\text { Percent of responding libraries, } \\
\text { each category }\end{array}$ \\
Four-year state & 3 & $23 \%$ (of 13)* \\
Four-year religious & 10 & $43 \%$ (of 23) \\
Four-year nondenominational & 3 & $43 \%$ (of 7) \\
Two-year state and private & 9 & $36 \%$ (of 25$)$ \\
Total & 25 & $35 \%$ (of 68$)$
\end{tabular}

*Percentages in the text and in all tables have been adjusted to the nearest whole-number. 
percent of challenges. The more conservative the theological foundation for the school, the greater likelihood for censorship in the library, but not by much. Librarians working in this type of academic setting need to be aware of the possibility for censorship to the collection, and should prepare for the likelihood of challenges to the collection.

After establishing the existence of challenges to the library, the respondents answering in the positive responded to a series of questions concerning classifications of censorship. The following numbers represent individual libraries, even if multiple challenges occurred. Eleven individual libraries ( $16 \%$ of total respondents) reported a request to remove material from their collections; 14 libraries (21\%) encountered problems with anonymous tampering, mutilation, or destruction with library computer hardware and library-sponsored bulletin boards, while four libraries $(6 \%)$ recorded formal challenges that did not require the removal of material from the collection. Cases reported as tampering were examined carefully. One can presume, sadly, that nearly every library experiences random tampering and mutilation, sometimes in lieu of photocopying or as an exhibition of a prurient interest in photographs or drawings involving sexual topics. Nonetheless, certain related incidents reported by the respondents clearly indicated a form of censorship, and the author relied heavily, but not exclusively, upon the beliefs of the responding librarians concerning their definition of cases of censorship. The survey also inquired if the libraries had experienced requests to relocate material from one part of the collection to another in order to restrict it. Although several respondents indicated incidents for this question, none of the cases could be regarded as true cases of censorship. They involved requests to recatalog items from one part of the collection to another and were not recorded as incidents of censorship in the author's results.

As recorded earlier, 25 libraries reported 38 cases of censorship. Not surprisingly, the traditional categories of books and journals received the greatest number of complaints (see table 3 ). However, the combined categories of art work (tied for second place with journals) and bulletin boards demonstrate the fact that a library can encounter problems in nontraditional areas. Library-sponsored art exhibits and individual works of art adorning the walls and bulletin boards needed to be included in this survey. They are an integral and special part of many college libraries, and these exhibits and bulletin boards also encounter the same

\begin{tabular}{|c|c|c|c|c|c|c|c|}
\hline \multicolumn{8}{|c|}{$\begin{array}{c}\text { TABLE } 3 \\
\text { CATEGORIES OF CENSORSHIP }(\mathrm{N}=38)\end{array}$} \\
\hline & Books & Journals & $\begin{array}{l}\text { Art } \\
\text { work }\end{array}$ & Videotapes & $\begin{array}{l}\text { Bulletin } \\
\text { boards }\end{array}$ & $\begin{array}{l}\text { Computer } \\
\text { software }\end{array}$ & Building \\
\hline Removal & 10 & 6 & $\mathbf{x x}$ & 2 & $x x$ & $x x$ & $\mathrm{xx}$ \\
\hline Tampering & 4 & 2 & 4 & $x x$ & 2 & 2 & 1 \\
\hline Complaints & $x x$ & $x x$ & 4 & 1 & $x x$ & $\mathbf{x x}$ & $x x$ \\
\hline Total & 14 & 8 & 8 & 3 & 2 & 2 & 1 \\
\hline Percent( of 38)* & 37 & 21 & 21 & 8 & 5 & 5 & 3 \\
\hline
\end{tabular}


sorts of problems and challenges that occur with books and journals. Rounding out the field were problems with videotapes and computer software.

The identifiable subject matter for these complaints breaks down into various categories. As one would expect, material dealing with sexual themes led the list with 15 challenges. This was followed by material that could be considered: po-

Examined by individual categories, the religious and nondenominational colleges are remarkably similar, with very high rates of experienced censorship.

litical (five complaints); violent (four); racist (four); religious (two); dealing with animal rights (one); and offensive, but not sexually offensive (one). A specific subject could not be assigned to some of the incidents reported: this accounts for the disparity between number of complaints (38) and number of subjects (30). With little overlap, the items singled out by complainants reported in the survey display a wide variety of titles and materials. Respondents mentioned Playboy twice in both the American and Canadian surveys. There was more of an overlap with the Christian libraries study because of the shared time frame of the two studies; the Canadian study examined censorship in libraries a decade ago. The descriptive designations supplied by the respondents and titles that met with challenges are provided in table 4 . Specific editions are indicated only when known, and shared titles with the Canadian and Christian libraries studies are indicated in brackets. When noted, the dates of the complaint or incident are supplied. In the category "art works," the type of artistic medium was not indicated for the items listed as "depictions."

Some of the challenged items have their own individual histories in the realm of intellectual freedom. The homoerotic photography of Robert Mapplethorpe received national attention after the artist and his work gained notoriety in 1989 because of a public campaign of "decency" generated by Senator Jesse Helms. ${ }^{8}$ In the two reported cases involving books by Mapplethorpe, the titles were kept in the libraries after discussion with the complainants. Homosexual material also caused problems at other libraries. One library had two separate incidents in the summer and fall months of 1992 when several books on homosexuality were removed from the shelves and placed in trash cans throughout the library, including the men's rest room. The library had a creative and effective response to this problem: a display was set up in the library with the notice, "Someone would like to prevent you from reading these books," and an accompanying article appeared in the student newspaper. There have been no such incidents since at this particular library. Another library, contemplating the subscription to the journal The Advocate, received protests from library staff members who objected to the possibility of handling a homosexual journal. The end result in this situation is not clear. The respondent did not specify whether or not the library subscribed to the journal.

The explicit sexual photographs in Caught Looking, a feminist perspective on pornography edited by Kate Ellis, also came under attack. A local businessman instigated the complaint against this title, but the library in question kept the book after discussing the situation with the complainant. No list of challenged items in libraries would be complete without the perennial favorite Playboy. As previously mentioned, this title was listed twice by respondents. In one situation, a member of the library's Board of Trustees challenged this magazine, questioning the use of library funds for this title. A letter of explanation and a formal presentation to the board by the library resulted in the magazine's being kept in the 


\section{TABLE 4 \\ Items Challenged}

Subject/Title/Description

Date of Complaint/

Incident (if known)

Books:

Andy Warhol Prints, edited by F. Feldman and J. Schellmann, 1985 [Christian*]

Caught Looking, edited by Kate Ellis et al, 1992

1993

Daddy's Roommate, by Michael Willhoite, 1990 [Christian]

1993

Encyclopaedia Britannica [Christian]

The Limerick: 1700 Examples, edited by Gershon Legman, 1970

Little Black Sambo, by Helen Bannerman

Robert Mapplethorpe, by Richard Marshall, 1988 [Christian]

Nov. 1992

1989

1991

Book of photography by Robert Mapplethorpe [Christian]

1991

Book on sexual relationships

Dec. 1993

Book on rape

Books on homosexuality - two incidents reported, titles not supplied

1992

Anti-Mormon books

1989

An atlas

Dec. 1993

Journals:

The Advocate

American Atheist

Animal's Agenda

Heavy Metal

Playboy - two respondents in American colleges survey

[Canadian**; Christian]

Soldier of Fortune

$1991, ?$

$1991 / 92$

Village Voice

\section{Videotapes:}

Aristophanes' Lysistrata, distributed by Greek Video, 1987 [Christian] A Clockwork Orange, directed by Stanley Kubrick, 1971 [Christian]

The Virgin Spring, directed by Ingmar Bergman, 1960

1992

May 1993

Oct. 1993

\section{Art Works:}

Depiction: Nudes

Depiction: Portrait of Nazi leader, Heinrich Himmler

Drawing: Klansmen threatening an African-American man

Photography: Portrait of a university professor

Photography: Exhibit chronicling the lives of terminal cancer patients

Photography: Subject "inappropriate"

Mar. 1991

Poster: The life of Dr. Martin Luther King Jr.

Feb. 1994

Poster: Celebration of Black History Month

*Reported in Christian libraries by Hippenhammer.

**Reported in Canadian libraries by Schrader, Herring, and De Scossa.

Dec. 1993 
collection: In the second Playboy case, several complaints-verbal, written, and sent to an electronic suggestion boxagainst the title resulted in the subscription being cancelled, but only after the library budget required a reduction of several thousand dollars worth of serial subscriptions. In this particular situation, the library's problem was solved by external factors, i.e., the budget. Playboy also gains distinction as being the only title shared by all three censorship studies of academic libraries: American, Canadian, and Christian colleges.

Sexual themes also were behind the challenges to other items reported by American college libraries. One student declared The Limerick, edited by Gershon Legman, offensive, and it was placed tem-

\section{An unnamed but obviously current atlas was challenged when a student complained over its depiction of Macedonia as a separate country instead of as a region of Greece.}

porarily on reserve. Meanwhile, the librarians examined their collection development policy, discussed the book with three faculty members and a dean of the college, and decided that the proper procedure was to return the book to the regular collection. Book mutilation, which was judged by the respondents and the author to be a case of censorship, involving sexual material was inflicted upon one library's copy of Andy Warhol Prints. Several students objected to a videotape of Aristophanes' Lysistrata, a Roman play dealing with the power of sexual relations. At this institution, the library requested intervention by the president of the college, who reviewed the material and returned it to the library with the indication that it should remain in the collection. At yet another college, a library staff employee voiced an objection to a depiction of nudes on display in the library. The library administration dis- cussed the incident with the staff member and the art work remained on display.

Although levity is not a normal feature of cases of censorship, one can be permitted a small restrained chuckle over one reported incident of mistaken identity. The author of a book on sexual relationships shared the same name with a faculty member at one institution. The book's existence in the collection came to the attention of the faculty member when the views espoused in the book, which had been read by a student, contradicted the faculty member's opinions stated in class. The library agreed to withdraw the title because of the faculty member's strong views in opposition to the ideas found in the book, and to eliminate problems of identification between the author and the faculty member. Is this censorship? It is not always easy to say with complete confidence and assuredness.

The turbulent world of children's literature also invaded the placid world of the college library. Helen Bannerman's children's classic Little Black Sambo, first published in London in 1899, had fallen from grace long ago and was challenged at one college. Little Black Sambo was cited by a faculty member as an example of racist literature and no longer appropriate for use by children's literature classes. The library's solution was to move the book to the rare book collection to be used by upper-division students studying censorship and racism in children's literature. This solution appears valid; the title remains available and the book is less likely to undergo further challenges. Michael Willhoite's children's book Daddy's Roommate, which introduces children to the lifestyle of a gay male couple, has had a tumultuous history of challenges in school and public libraries since its publication in $1990 .{ }^{9}$ In the survey, one respondent reported that a student and an alumnus requested the removal of this title from its library's children's literature collection; the book was kept in the library after discussion with the complainants. 
An entire censorship case history involving Daddy's Roommate and the Minot State University (MSU) library, from first complaint through final resolution, is recounted by Susan Podrygula in CERL News. This particular case is of interest since MSU in Minot, North Dakota, with a student population of 3,800 , matches the profile of colleges in the present survey. As Podrygula recounts: "[We] were surprised when it happened to us. ... Six months after we received the initial letter of complaint, we are in the midst of revising and updating our collection development statement. This experience will make us examine more closely the section on censorship and intellectual freedom, so routinely included in collection development policies, but never really expected to be used."10

Challenges related to politics, religion, and violence also occur in college libraries. Students objected to the possession of various journals: The Advocate, American Atheist, Animal's Agenda, Heavy Metal, Soldier of Fortune, and the Village Voice. In several instances, the form of protest was actualized as theft or mutilation, but it was perceived as censorship by the library. Except for Animal's Agenda, which was relocated behind the circulation desk to protect the issues from damage, the resolution to the other journals' continuing existence in their respective libraries is unclear. Reference collections were not considered to be sacrosanct: an atlas and an encyclopedia came under fire. An unnamed but obviously current atlas was challenged when a student complained over its depiction of Macedonia as a separate country instead of as a region of Greece. The atlas was kept in the collection. The essay on "Sex," in the Encyclopaedia Britannica (edition not reported) at a different college was razorbladed out of the volume; the library regarded this act as censorship.

From a different library came the report of a complaint registered by a local Mormon church member who objected to the library's ownership of several titles perceived to be anti-Mormon. The library demonstrated that it provided a balance by owning several publications produced by the Church of the Latter Day Saints. After the librarian talked to the complainant, no further action was taken. The books remained on the shelf.

Racist censorship appeared in several guises. Two librarians reported posters stolen from library displays: one on the life of Dr. Martin Luther King Jr. and another celebrating Black history month. A drawing in a library-sponsored art show created a furor at one college. The African-American artist depicted local businessmen and police as Klansmen threatening the artist. When the library refused to remove the piece after complaints from one of the subjects, the complainant attempted to rip the drawing from the wall. The library intervened, a discussion with the complainant was held, and the drawing remained in the library and art show. This incident brings to mind a famous case of Renaissance censorship involving a conflict between Michelangelo and the papal chamberlain Biagio da Cesena who protested his depiction as a denizen of hell in the artist's "The Last Judgment" (1535-1541) in the Sistine Chapel. Pope Paul III refused papal intervention and Biagio remained pictorially consigned to the netherworld. In the modern parallel, the complainant remained in the Klan.

Naturally, some censorship problems did not fit into the above categories. In two separate institutions, someone tampered with computer software, removing programs from the library hard drive in one college, and replacing instructional terms on a menu program with obscene terms at another. Three additional schools reported attacks against the library facilities or contents: a swastika was painted on the entrance to the library, spotted by campus police at 5:30 a.m., and removed before the building opened at 8:00 a.m.; an art show in the library was defaced by graffiti; and a photograph of a university 
professor in a library exhibit was defaced. The remaining problems centered around art work in the library. Photographs by faculty members were regarded as inappropriate in one instance-the subject matter not identified-and a photographic chronicle of the lives of terminally ill cancer patients was labeled distasteful in another. Both cases occurred at the same college, but two years apart, 1991 and 1993. A portrait in a library show by a former faculty member of the Nazi leader Heinrich Himmler, although a negative portrayal, still raised the ire of one student. In the latter three instances, after discussion with the complainant, the problematic works of art remained on exhibit in the libraries.

Students comprise the largest portion of the population at the colleges associated with the libraries in the survey. It is not unexpected to discover that students are the largest identifiable group instigating complaints against the collection (see table 5). Actually, the category of unknown assailants tops the list in the area of tampering and destruction of library materials. Although many respondents indicated that these perpetrators of violence were likely students, no actual proof exists. If this is true, then the number of students formally or anonymously creating a censorship challenge to the library could be as high as 63 percent out of the total number of recorded incidents. It seems quite plausible that this percentage is a more likely figure for studentoriginated complaints or incidents: students have great unrestricted access to the libraries' collections. Conversely, if the category of unknown assailants is removed from consideration, the number of students registering complaints is at 44 percent (out of 25 cases). In the Canadian study by Schrader, Herring, and De Scossa, the authors reported a 40 percent origination of complaints by students and teaching staff, while Hippenhammer recorded a surprising 84 percent of challenges coming from students alone. ${ }^{11}$ If one accepts either the combined figure of 63 percent (unknown plus student complainants), or only permits the total of 44 percent student complaints, the present survey of American colleges falls between the range of the Canadian and Christian college surveys. Whether one accepts the higher or lower figure in the present survey, one cannot deny the fact that, in the American and Christian surveys, college

\section{TABLE 5}

\section{Complainants}

\begin{tabular}{lccccc}
\hline \hline & $\begin{array}{c}\text { \# of com- } \\
\text { plainants }\end{array}$ & $\begin{array}{c}\text { Percent } \\
(\mathrm{N}=38)\end{array}$ & $\begin{array}{c}\text { \# of com- } \\
\text { plainants }\end{array}$ & $\begin{array}{c}\text { Percent } \\
(\mathrm{N}=25)^{*}\end{array}$ \\
\cline { 2 - 3 } $\begin{array}{l}\text { Unknown } \\
\text { Student }\end{array}$ & 13 & 34 & $\mathrm{xx}$ & $x x$ \\
Students and unknown (combined) & 24 & 63 & 11 & 44 \\
Member of teaching staff (faculty) & 5 & 13 & 5 & 20 \\
Member of library staff & 3 & 8 & 3 & 12 \\
Community member & 3 & 8 & 3 & 12 \\
Administrative official of the institution & 1 & 3 & 1 & 4 \\
Community religious organization & 1 & 3 & 1 & 4 \\
Alumnus & 1 & 3 & 1 & 4 \\
Reported complainants, total & 38 & $101 \%$ & 25 & $100 \%$ \\
*These totals represent the elimination of unknown complainants/assailants & $(38-13=25)$. & \\
\hline
\end{tabular}




\section{TABLE 6}

Comparison among Complainants:

American, Canadian, and Christian Surveys

Unknown Students Faculty Staff Administrators Others Total

$\begin{array}{llllrrrr}\text { American } & 34 \% & 29 \% & 13 \% & 8 \% & 3 \% & 13 \% & 100 \% \\ \text { Canadian } & \text { xx } & \text { xx } & 40 \% * & 40 \% & 20 \% & \text { xxx } & 100 \% \\ \text { Christian } & \text { xx } & 84 \% & 21 \% & 23 \% & 5 \% & 28 \% & 161 \%\end{array}$

*This figure combines the totals for both students and faculty.

students institute the greatest number of complaints against the library, and this may also be true in the Canadian study. It is the youth that are the most conservative elements in the college environment. This fact alone seems to indicate strongly a definite need for greater library instruction and training for students, particularly in the area of intellectual freedom and censorship.

Following students on the list of complainants in the survey of American college libraries are: college faculty, library staff, community members, administrative officials, a community religious organization, and an alumnus. However, the three surveys do not agree in the figures for the percentage of complaints coming from faculty, library staff, and administrators (see table 6). The Canadian results do not divide the figures into smaller categories, and it is amazing that the authors found a 40 percent involvement by library staff members with incidents of censorship. Hippenhammer's survey totals are often much higher than 100 percent, and he appears to count multiple challenges in more than one category. This type of presentation is confusing and obfuscates the data, although it does not negate the results of his survey. ${ }^{12}$

Library officials treated the complaints in similar ways, exhibiting a unity of library policies concerning the handling of problems (see table 7). Although respondents reported 38 incidents, formal action was only given for 29 challenges. In the several cases of mutilation or theft that appear to be cases of censorship, there was no direct action taken or the action, if occurring, was not reported on the questionnaire.

Face-to-face communication, the foundation of the reference interview, was the

\section{TABLE 7}

\section{How Was the Incident Handled?}

Verbal discussion with complainant, no further action taken

Material relocated

Written explanation sent to complainant, no further action taken

Computer software repaired/reloaded

Material removed/subscription cancelled

Replaced

Reviewed by administrative official

Warning label attached 
concluding factor for the majority of incidents. One might consider the discussion between librarian and complainant to be a library policy interview. In no reported case did the person instigating the challenge decide to continue beyond the stage of discussion. The complainants seemed to be satisfied that the libraries

\section{It is not unexpected to discover that students are the largest identifiable group instigating complaints against the collection.}

took their challenges seriously, had considered them, and made the effort to contact them for an explanation of the library's collection development policy. When materials were relocated, they still remained in the collection and available for examination and circulation purposes, but they were no longer accessible in the public domain, i.e., the general stacks. Only in two instances were items removed or a journal subscription cancelled. Thus, in 93 percent of the reported cases that presented some type of solution to the censorship problem at hand, the library retained the problem items. It appears that when challenged, college libraries make a concerted effort to retain the questioned materials and to inform the complainant of the reasons for the library's decisions.

One observation is the difficulty in identifying what is and is not a case of censorship. It is easy to apply this rubric to situations where a patron approaches the library and submits a verbal or written complaint. It is harder to judge the motivations behind anonymous acts of tampering, theft, mutilation, and destruction committed against a library and its contents. When a researcher is dealing with surveys and relies upon the responses of others, levels of interpretation are involved: is the questionnaire understandable? are the respondents actually replying to the printed questions? and how shall the author interpret the responses? Unfortunately, identification of censorship is a subjective area and the author chose to err on the conservative side. If all reported cases of possible censorship were included in the recorded results, the figures of censorship would have been slightly higher. In this survey of American college libraries, the author examined the responses from each responding library and applied a subjective rating to each case of reported censorship. Instances involving known complainants were accepted as cases of censorship; cases involving anonymous acts were judged according to the statements supplied by the responding libraries. If the respondent believed an act of violence against the library was an act of censorship, the author accepted this judgment in most situations. Only in a limited handful of cases, involving stolen items of current popular interest or a request to move a title from the regular stacks to the reserve stacks in order to protect the contents from possible damage, did the author deem the cases not to be acts of censorship. Nonetheless, 19 situations in 15 libraries were identified, out of the total 38 reported and accepted instances of censorship, where known complainants were involved.

\section{Conclusion}

This study should provide an alert for the college library community. Censorship is a part of the college library reality, and librarians need to be aware of this fact and to be prepared for the eventuality of it happening at their institution. One-third of the libraries surveyed have already experienced this phenomenon. For libraries that have already experienced a censorship challenge, complacency should be discouraged. Censorship lightning can strike multiple times in the same location. The results of the survey of American college libraries indicates the importance of campuswide library instruction to heighten student, faculty, and library staff 
awareness of the issues of censorship and intellectual freedom. When possible, and particularly in small communities where the college is the hub for many local activities, there is a definite need to develop an outreach relationship with members of the community representing business, religious, and political organizations.

Reported challenges and problems occurred in nontraditional areas under a library's control: art shows, bulletin boards, computer software, and librarysponsored events. One can only hazard a guess that as libraries move heavily into the computer network environment, people will devise new and more creative ways to censor and challenge the library. Who knows what forms of censorship challenges the information superhighway will produce? To be prepared for the future eventuality of a censorship problem, in any format, librarians need to arm themselves fully with carefully prepared policies, reconsideration forms, and the backing of administrators. Forewarned is forearmed. As always, the best defense for the library environment is education: the better informed the users of the library are concerning intellectual freedom, the less likely they are to want to censor.

\section{Notes}

1. The first published study of censorship in college libraries appears to be the article by Alvin M. Schrader, Margaret Herring, and Catriona de Scossa, "The Censorship Phenomenon in College and Research Libraries: An Investigation of the Canadian Prairie Provinces, 1980-1985," College \& Research Libraries 50 (July 1989): 420-32. This was followed by Craighton Hippenhammer's bipartite set: "Patron Objections to Library Materials: A Survey of Christian College Libraries Part I," Christian Librarian 37:1 (Nov. 1993): 12-17; "Patron Objections to Library Materials: A Survey of Christian College Libraries Part 2," Christian Librarian 37 (Feb. 1994): 40-47; and the summary of his survey, "Intellectual Freedom in Christian College Libraries," Newsletter on Intellectual Freedom 43 (Mar. 1994): 41, 50.

2. Schrader et al., "The Censorship Phenomenon," 426. Inspiration for this project was provided by Margaret Herring's groundbreaking study, "The Effectiveness of Written Selection Policies in Preventing Censorship in Academic Libraries in the Prairie Provinces Since 1980," (M.L.S. research project, University of Alberta, 1986). Herring granted permission to utilize her original survey as the basis for my questionnaire. In this manner, I could make acceptable comparisons between Canadian and American libraries.

3. Peterson's Register of Higher Education, 1994 (Princeton, N.J.: Peterson's Guides, 1993), includes information on almost 3,700 colleges and universities in the United States.

4. Under the category of total enrollment, 15 percent of the schools have a student population of 501 to 1,000 , while student bodies numbering 1,001 to 5,000 represent 40 percent. Colleges with an enrollment of 501 to 5,000 equal 55 percent of the number of postsecondary institutions; Peterson's Register: xxiv.

5. Schrader et al., "The Censorship Phenomenon," 422.

6. Ibid., 422-23. The numbers were derived from "Table 1," but the authors did not present them in the fashion presented in the present essay.

7. Hippenhammer, "Patron Objections," I: 14.

8. The Mapplethorpe controversy has generated much press, a small sampling includes: Margaret Carlson, "Whose Art Is It Anyway?" Time 134:1 (July 3, 1989): 22-23; Leo John, "Ugly Truths Untold by the Press," U.S. News \& World Report 109 (Sept. 10, 1990): 23; Jacob Neusner, "The End of the N.E.A.," National Review 43 (May 13, 1991): 39-41.

9. The literature on Daddy's Roommate is extensive, but an informative summary of the controversy can be found in Mary Jo Godwin's "Conservative Groups Continue Their Fight to Ban Daddy's Roommate," American Libraries 23 (Dec. 1992): 968.

10. Susan Podrygula, "Censorship in an Academic Library," College \& Research Libraries News 55 (Feb. 1994): 76-78, 83.

11. Schrader et al., "The Censorship Phenomenon," 424; Hippenhammer, "Patron Objectives," I: 14.

12. Hippenhammer has a consistent flaw in methodology in presenting figures that do not tally to 100 percent. 


\section{PAINT YOUR OWN PICTURE W I T H FIR S T S E A R C H}

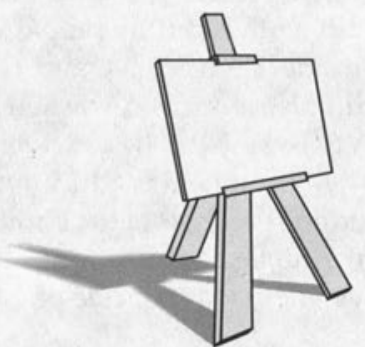

FOR MANY LIBRARIES, PROVIDING REFERENCE DATABASES TO PATRONS has meant supporting a confusing hodgepodge of technologies, workstations, and services. Wouldn't it be nice if one system could simplify your efforts and meet most of your information needs? The FirstSearch service is the most adaptable patron reference system available today. Like an artist selecting colors, you have a wide range of options with FirstSearch to create the perfect reference picture for your library.

- Flexibility to choose databases

- Pricing flexibility-per search or flat fee

- Common user interface-yours or ours
- Remote and/or in-house access

- OCIC Dedicated Line, Internet, Dial Access

- Document Ordering and ILL

With FirstSearch, you have lots of flexibility, which is vital in a time of exploding choice and unpredictable change. You can tailor FirstSearch to fit in with today's patron service strategies - and tomorrow's.

Now is the time to paint the FirstSearch picture that's best for you.

\section{$1-800-848-5878$}

6565 Frantz Road, Dublin Obio 43017-3395

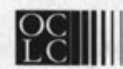

FURTHERING ACCESSTOTHE WORLD'S INFORMATION 